\title{
Influence of different concentrations of uric acid on oxidative stress in steatosis hepatocytes
}

\author{
SHI CHENG ${ }^{1}$, YAN YANG $^{2}$, YONG ZHOU $^{3}$, WEI XIANG $^{1}$, HUA YAO $^{4}$ and LING MA ${ }^{1}$ \\ ${ }^{1}$ Department of Nutrition and Food Hygiene, School of Public Health, Xinjiang Medical University; ${ }^{2}$ Department of Child \\ Healthcare, People's Hospital (Children's Hospital) North Hospital; ${ }^{3}$ Department of Biology, School of Basic Medicine, \\ Xinjiang Medical University, Urumqi, Xinjiang 830011; ${ }^{4}$ Health Management Department, The First Affiliated Hospital of \\ Xinjiang Medical University, Urumqi, Xinjiang 830054, P.R. China
}

Received September 5, 2017; Accepted January 23, 2018

DOI: $10.3892 /$ etm.2018.5855

\begin{abstract}
The development of nonalcoholic fatty liver disease (NAFLD) is caused by the steatosis of hepatocytes, which induces oxidative stress (OS). Thus, OS has an important role in the development of NAFLD. In the present study, the L-02 hepatocyte cell line was used to develop a steatosis cell model. The best model was determined using an MTT assay and the triglyceride levels. Model cells were treated with high concentrations of uric acid (UA; 0, 5, 10,20 and $30 \mathrm{mg} / \mathrm{dl}$ ) for 24, 48, 72 and $96 \mathrm{~h}$. Indicators of oxidation were then measured, which included total superoxide dismutase (SOD), malonaldehyde (MDA) and reduced glutathione (GSH), and the transcriptional and translational levels of SOD1 and $\gamma$-glutamate-cysteine ligase $(\gamma$-GCLC) were also determined. In addition, the intracellular levels of aspartate aminotransferase and alanine aminotransferase (ALT) were detected. The activity of SOD1 decreased over time and the result was supported by the results of western blotting. The transcriptional levels of SOD1 in model cells was significantly higher than untreated cells at $48 \mathrm{~h}$. With the decreased levels of SOD1 and GSH, MDA increased in a time-dependent manner. The content of GSH decreased with time as well, which was also reflected in the results of western blotting. The transcriptional levels of $\gamma$-GCLC in all UA-treated groups were lower when compared with those
\end{abstract}

Correspondence to: Professor Ling Ma, Department of Nutrition and Food Hygiene, School of Public Health, Xinjiang Medical University, 393 Xinyi Road, Urumqi, Xinjiang 830011, P.R. China E-mail: maling3633@126.com

Abbreviations: NAFLD, nonalcoholic fatty liver disease; U, uric acid; OS, oxidative stress; TG, triglyceride; MDA, malonaldehyde; SOD1, superoxide dismutase $1 ; \gamma$-GCLC, $\gamma$-glutamate-cysteine ligase; GSH, glutathione; ALT, alanine aminotransferase; AST, aspartate aminotransferase; ROS, reactive oxygen species; MTT, 3-(4,5-dimethylthiazol-2-yl)-2,5-diphenyl-2H-tetrazolium bromide;

Key words: glutathione, nonalcoholic fatty liver disease, superoxide dismutase 1, antioxidant, malonaldehyde observed in the model group. The activity of ALT tended to increase, depending on the duration of treatment. Treatment with 5 and $10 \mathrm{mg} / \mathrm{dl} \mathrm{UA}$ had an antioxidative effect on the model cells, and $30 \mathrm{mg} / \mathrm{dl}$ UA treatment for $48 \mathrm{~h}$ increased OS in the cells.

\section{Introduction}

The prevalence of nonalcoholic fatty liver disease (NAFLD) has increased rapidly, making it the most common cause of chronic liver disease in the developed world $(1,2)$. The pathogenic mechanism underlying NAFLD and its progression are not entirely understood. Accumulation of fat is an essential condition in the development of NAFLD (3), based on which hepatocyte oxidative stress starts causing injury to the liver, which accelerates the progression of NAFLD to more severe stages (4), such as non-alcoholic steatosis hepatitis, nonalcoholic fatty liver-related cirrhosis, and nonalcoholic fatty liver-related cancer (5). Oxidative stress (OS) is a condition of imbalance between the antioxidant defense mechanisms and the production of free radicals, which favors the latter, leading to potential damage (6). $\mathrm{OS}$ is one of the major contributors to the pathogenesis of NAFLD (7). Increased accumulation of liver TGs may cause increased OS in the hepatocytes of animals and humans (8). Many experimental models (9) and human studies (10-12) have shown a strong relationship between the severity of NAFLD and the degree of OS.

UA is a powerful scavenger of free radicals and was found to be able to scavenge $60 \%$ of free radicals in plasma (13). However, it is possible that an increase in circulating levels of UA represents an adaptive response to protect against the detrimental effects of excessive free radicals and OS. But we hardly to see the studies UA could protect cells in related diseases as an antioxidant. Although the antioxidant effect of UA suggests that it would have therapeutic effects, a high serum UA concentration is associated with obesity and NAFLD (14,15), and, some possible mechanisms had been presented. In recent study, UA could protect brain health as an antioxidant, especially the level in acute raising (16), so we guess that the same effect may occur in the liver. If the assumption is true, the researches of UA in NAFLD would 
make a change, the mechanism would more complex in human body.

The purpose of our study was to investigate whether UA can ameliorate OS in hepatic steatosis and the optimal concentration for this effect. Therefore, we tested the enzyme activities of glutathione (GSH), transcriptional and translation levels of $\gamma$-glutamate-cysteine ligase $(\gamma$-GCLC) and superoxide dismutase 1 (SOD1) in both untreated and model cells that were treated with different concentrations of UA. We also examined the levels of malonaldehyde (MDA), alanine aminotransferase (ALT), and aspartate aminotransferase (AST) to reflect the level of OS and cell damage.

\section{Materials and methods}

Cell culture. HL-7702 cells (KeyGen Biotech Co., Ltd., Nanjing, China), hereafter referred to as L-02 cells, were maintained in high-glucose Dulbecco's minimum essential medium with $10 \%$ fetal bovine serum (Gibco; Thermo Fisher Scientific Inc., Waltham, MA, USA) and $0.5 \%$ penicillin-streptomycin solution (HyClone; GE Healthcare Life Sciences, Logan, UT, USA). L-02 cells were grown in $25-\mathrm{cm}^{2}$ culture bottles (Corning Inc., Corning, $\mathrm{NY}, \mathrm{USA}$ ) at $37^{\circ} \mathrm{C}$ with $5 \% \mathrm{CO}_{2}$.

Developmentof a steatosis cell model. The method for dissolving oleic acid (OA) and developing a steatosis cell model was similar to that previously published by Wang et al (17). Briefly, OA (Sigma-Aldrich; Merck KGaA, Darmstadt, Germany) and $\mathrm{NaOH}$ were mixed in ultrapure water, and the solution was added to the standard medium to prepare a sodium oleate medium with OA concentrations of $0.1,0.2,0.3$, and $0.4 \mathrm{mM}$.

Cell activity measured by MTT. Cells were inoculated into 96-well plates at a density of $1 \times 10^{3}$ cells/well and treated with five different concentrations of OA using six wells per concentration. After 24 h, $20 \mu \mathrm{l}$ of MTT (M6494; Thermo Fisher Scientific, Inc.) was added to a final concentration of $5 \mathrm{mg} / \mathrm{ml}$ into all wells without removing the oleic acid medium. After incubating for $4 \mathrm{~h}$ at $37^{\circ} \mathrm{C}$, the media was removed and $150 \mu \mathrm{l}$ DMSO was added into the wells with 10 min of shaking. The absorbance at $570 \mathrm{~nm}$ was then measured in microplate reader (Bio-Rad Laboratories, Inc., Hercules, CA, USA). We found the viability of cells treated with $0.4 \mathrm{mM}$ sodium oleate were significantly lower than that of untreated cells. Hence, the $0.4 \mathrm{mM}$ condition was not used in further analysis.

Triglyceride (TG) measurement. The cells were inoculated into 6-well cell culture plates at a density of $3 \times 10^{5}$ cells/well for four different OA treatment groups. The intracellular TG concentration was determined using a TG measurement kit according to the manufacturer's instructions (Nanjing Jiancheng Bioengineering Institute, Nanjing, China).

Treatment with UA. Cells were inoculated into 6-well culture plates at a density of $3 \times 10^{5}$ cell/well. UA at concentrations of $5,10,20$, and $30 \mathrm{mg} / \mathrm{dl}$ was added to both model and untreated cells. The cells were incubated for 24,48 , 72 , and $96 \mathrm{~h}$. A UA concentration of $5 \mathrm{mg} / \mathrm{dl}$ is known as the normal blood UA level; a level of $10 \mathrm{mg} / \mathrm{dl}$ and higher is considered hyperuricemia (18).
Detection of oxidative stress. The activity of total SOD and the content of GSH and MDA were used to reflect the level of oxidative stress. All parameters were measured using appropriate kits from Nanjing Jiancheng Bioengineering Institute (A001-3, A003-4, A006-2). The transcription levels of SOD1 and $\gamma$-GCLC were detected by a two-step quantitative reverse transcriptase PCR (RT-qPCR). Briefly, total mRNA was extracted from the cells using RNAiso Plus (Takara Biotechnology Co., Ltd., Dalian, China). The mRNA was reverse transcribed into cDNA using a First Strand cDNA Synthesis kit according to the manufacturer's instructions (Thermo Fisher Scientific, Inc.). $\beta$-actin was used as a control for the qPCR. The denaturation temperature for all three mRNA sequences was $95^{\circ} \mathrm{C}$. The annealing temperatures were 58,5 , and $57^{\circ} \mathrm{C}$ corresponding to $\mathrm{Zn} / \mathrm{Cu} \mathrm{SOD}, \gamma$-GCLC, and $\beta$-actin, respectively. After running 40 cycles, the melting curves were drawn by the software of IQ5. Three wells were used per condition. The primers for SOD1 were designed by Invitrogen, and the primers for $\gamma$-GCLC were designed by BGI. The sequences are shown in Table I.

The translation of SOD1 and $\gamma$-GCLC were determined by western blotting. Total protein was extracted using RIPA solution (Thermo Fisher Scientific, Inc.). Sample buffer (4X; Solarbio Science and Technology Co., Ltd., Beijing, China) was added to $40 \mu \mathrm{g}$ protein at a ratio of 1:3 (v:v) and was then heated at $95^{\circ} \mathrm{C}$ for $5 \mathrm{~min}$ for degeneration. SDS-polyacrylamide gel was made using a SDS-PAGE kit (Solarbio Science and Technology Co., Ltd.). Prestained protein ladder (8 $\mu \mathrm{l})$ (26616; Thermo Fisher Scientific, Inc.) was added into one lane of the gel and $40 \mu \mathrm{g}$ of the protein sample was added into the other lane. The electrical current was $25 \mathrm{~mA}$ per gel and the voltage of electrotransfer was $60 \mathrm{~V}$ per sandwich running for $1 \mathrm{~h}$. The membrane was blocked with blocking buffer (CWBio, Beijing, China) for $1 \mathrm{~h}$. The primary antibody of SOD1 (ab20926) and $\gamma$-GCLC (ab55435) (both from CWBio, Beijing, China) were diluted with TBST (CWBio) at a ratio of 1:1,000. After washing with TBST, the membrane was then incubated with the primary antibody diluent overnight at $4^{\circ} \mathrm{C}$. The secondary antibody (Booster Bioengineering Institute, Wuhan, China) was diluted with TBST at a ratio of 1:8,000. The membranes were incubated with the secondary antibody diluent for 90 min under $25^{\circ} \mathrm{C}$. Washed membranes were incubated with BCIP/NBT KIT (002209; Thermo Fisher Scientific, Inc.) for $10 \mathrm{~min}$, taken pictures in GelDoc XR System (Bio-Rad Laboratories, Inc.). The grayscale of photos was analyzed by Quantity One software.

Statistical analysis. All of the data were analyzed using SPSS 23.0 and tested for normality and the homogeneity of variance. If the data showed normality and had equal variance, one-way analysis of variance (ANOVA; F distribution) was used. If there were significantly differences from the mean among all the groups, Tukey's method was used to complete multiple comparisons. If the data showed normality, but did not have equal variance based on one-way ANOVA, the Brown-Forsythe method was used to correct the results. For multiple comparisons based on unequal variance data, the Games-Howell method was used. If the data did not show normality, the Kruskal-Wallis H test was used, which is one of the non-parametric methods. 
Table I. Primer sequences of SOD1 and $\gamma$-glutamate-cysteine ligase.

Gene

Forward (5'-3')

Reverse (3'-5')

$\begin{array}{ll}\mathrm{Cu} / \mathrm{Zn} \text { SOD } & \text { AGGGCATCATCAATTTCGAGCAG } \\ \gamma \text {-GCLC } & \text { AGATGATAGAACACGGGAGG } \\ \beta \text {-actin } & \text { GTCCACCTTCCAGCAGATGTG }\end{array}$

CCACAAGCCAAACGACTTCCAG

$\beta$-actin

GTCCACCTTCCAGCAGATGTG

SOD, superoxide dismutase; $\gamma$-GCLC, $\gamma$-glutamate-cysteine ligase.

\section{Results}

Development of a steatosis cell model. We tested cellular viability by an MTT assay to ensure that the OA concentrations used did not impact metabolic activity. As shown in Fig. 1A, $0.4 \mathrm{mM}$ OA showed a significant decrease in cellular activity and, thus, this condition was excluded from subsequent experiments. Next, we found that the $0.3 \mathrm{mM}$ treatment group showed the highest TG concentration (Fig. 1B). Thus, the condition of $0.3 \mathrm{mM}$ OA was chose.

Detection of oxidative stress. The purpose of our study was to detect the variations in oxidative stress in the steatosis cells after treatment with UA. As a result of the antioxidative abilities of UA, we predicted that after treatment of steatosis cells with UA, the oxidative stress should be lowered, especially with low concentrations of UA.

The MDA (Fig. 1C) content of model cells was higher than that of untreated cells at all time-points $(\mathrm{P}<0.05)$. All the UA-treated groups showed no significantly differences compared with the untreated groups at $24 \mathrm{~h}(\mathrm{P}>0.05)$. With an increase in treatment duration, the 5 and $10 \mathrm{mg} / \mathrm{dl}$ group had lower MDA levels than the model group $(\mathrm{P}<0.05)$, and the MDA level of the $10 \mathrm{mg} / \mathrm{dl}$ group was closest to that of the untreated group. However, the 20 and $30 \mathrm{mg} / \mathrm{dl}$ treatments could not stop the accumulation of MDA in the model cells after 72 and $96 \mathrm{~h}$, respectively.

The GSH content (Fig. 2A) of model cells was lower than that of untreated cells $(\mathrm{P}<0.05)$. All the treated groups show an increasing at different time-point. All four concentrations of UA elevated the GSH content in steatosis cells at $24 \mathrm{~h}$ $(\mathrm{P}<0.05)$. UA at concentrations of 20 and $30 \mathrm{mg} / \mathrm{dl} \mathrm{did}$ not elevate the GSH concentration in steatosis cells any further after $24 \mathrm{~h}(\mathrm{P}<0.05)$, and had no difference compared with model cells $(\mathrm{P}>0.05)$ as well as the $10 \mathrm{mg} / \mathrm{dl}$ group after $72 \mathrm{~h}$ $(\mathrm{P}<0.05)$. However, after treatment with $5 \mathrm{mg} / \mathrm{dl} \mathrm{UA}, \mathrm{GSH}$ content was higher than it in the model group over the course of the experiment.

In the transcription results for $\gamma$-GCLC (Fig. 2B), there were no statistically significantly differences between the model group and the untreated group $(\mathrm{P}>0.05)$. The $30 \mathrm{mg} / \mathrm{dl}$ treatment group showed higher transcription levels than the model group $(\mathrm{P}<0.05)$. Only the $10 \mathrm{mg} / \mathrm{dl}$ group after $72 \mathrm{~h}$ had levels lower than that of the untreated group $(\mathrm{P}<0.05)$. The other groups did not show statistically significantly differences compared to the untreated group at any time-point $(P>0.05)$. The translation of $\gamma$-GCLC (Fig. 2C and D) in the model group was higher than that in the untreated group at

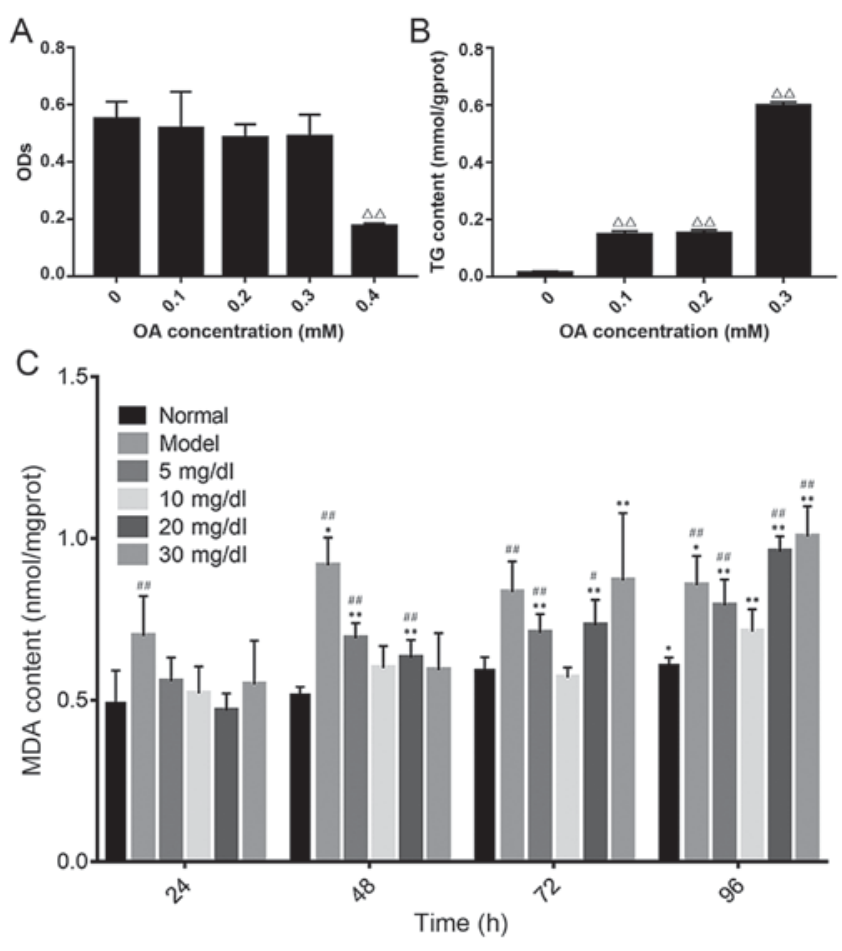

Figure 1. Vitality and TG content in cells treated with different concentrations of OA, and the MDA content in cells treated with UA. (A) Cells were treated with 4 different concentrations of OA (0.1-0.4 mM), and the vitality of cells and the (B) TG content were assessed. (C) Steatosis cells were treated with UA at different concentrations $(0,5,10,20$ and $30 \mathrm{mg} / \mathrm{dl})$ for different durations $(24,48,72$ and $96 \mathrm{~h})$; untreated cells were used as the control. The $0.4 \mathrm{mM}$ sodium oleate treatment was removed due to its low vitality of cells. ${ }^{\Delta \Delta} \mathrm{P}<0.01$ vs. untreated cells; ${ }^{*} \mathrm{P}<0.05$ and ${ }^{* * *} \mathrm{P}<0.01$ vs. 24 h cells at the corresponding UA concentration; ${ }^{\#} \mathrm{P}<0.05$ and ${ }^{\# \#} \mathrm{P}<0.01$ vs. control cells at the corresponding time-point. TG, triglyceride; OA, oleic acid; UA, uric acid; MDA, malondialdehyde.

all four time-points $(\mathrm{P}<0.05)$. The $5 \mathrm{mg} / \mathrm{dl}$ group had a lower translational level than the model group, and the $30 \mathrm{mg} / \mathrm{dl}$ group showed elevated translation at $96 \mathrm{~h}$ in the steatosis cells. The $10 \mathrm{mg} / \mathrm{dl}$ group at 24 and $72 \mathrm{~h}$ and the $20 \mathrm{mg} / \mathrm{dl}$ group at 24,48 , and $96 \mathrm{~h}$ showed decreased levels of $\gamma$-GCLC in the steatosis cells $(\mathrm{P}<0.05)$.

The activity of SOD1 (Fig. 3A) in the model cells was not lower than that of the untreated cells, especially at $24 \mathrm{~h}$ $(\mathrm{P}<0.05)$, and there were no statistically significantly differences between the two groups from 48 to $96 \mathrm{~h}$. The $5 \mathrm{mg} / \mathrm{dl} \mathrm{UA}$ group had elevated SOD activity compared to the untreated group $(\mathrm{P}<0.05)$, and the $30 \mathrm{mg} / \mathrm{dl} \mathrm{UA}$ group showed reduced SOD activity compared to the untreated group at $96 \mathrm{~h}(\mathrm{P}<0.05)$. The transcription level of SOD1 (Fig. 3B) in model cells was 

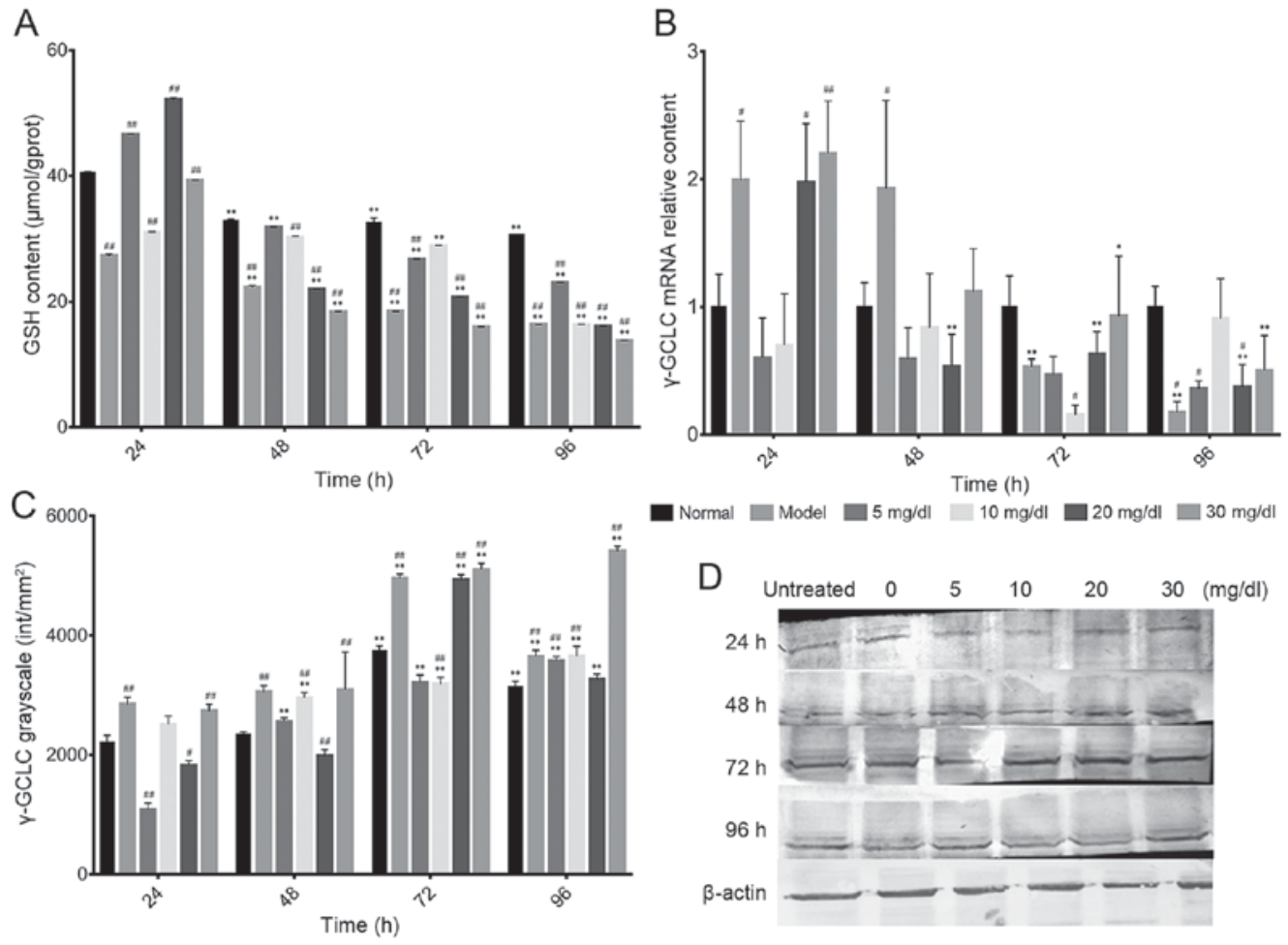

Normal $\square$ Model $\square 5 \mathrm{mg} / \mathrm{dl} \square 10 \mathrm{mg} / \mathrm{dl} \square 20 \mathrm{mg} / \mathrm{dl} \square 30 \mathrm{mg} / \mathrm{dl}$

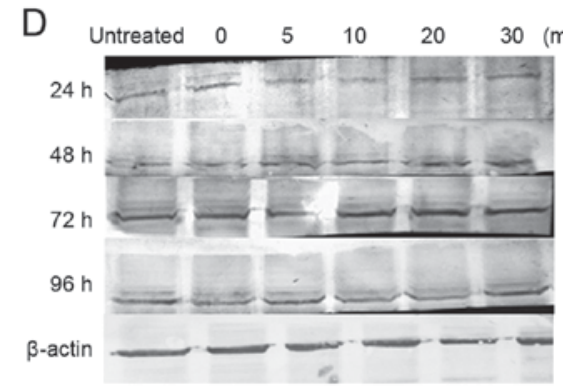

Figure 2. GSH content and the expression (transcriptional and translational) of $\gamma$-GCLC. The steatosis cells were treated with UA at different concentrations $(0,5,10,20$ and $30 \mathrm{mg} / \mathrm{dl})$ and for different durations $(24,48,72$ and $96 \mathrm{~h})$; untreated cells were used as the control. (A) GSH content, (B) $\gamma$-GCLC mRNA expression and (C) $\gamma$-GCLC protein expression were then measured. (D) Western blotting was performed to determine protein expression. ${ }^{*} \mathrm{P}<0.05$ and ${ }^{* *} \mathrm{P}<0.01$ vs. $24 \mathrm{~h}$ cells within the same UA concentration; ${ }^{\#} \mathrm{P}<0.05$ and ${ }^{\# \#} \mathrm{P}<0.01$ vs. control cells at the corresponding time-point. GSH, glutathione; UA, uric acid; $\gamma$-GCLC, $\gamma$-glutamate-cysteine ligase.
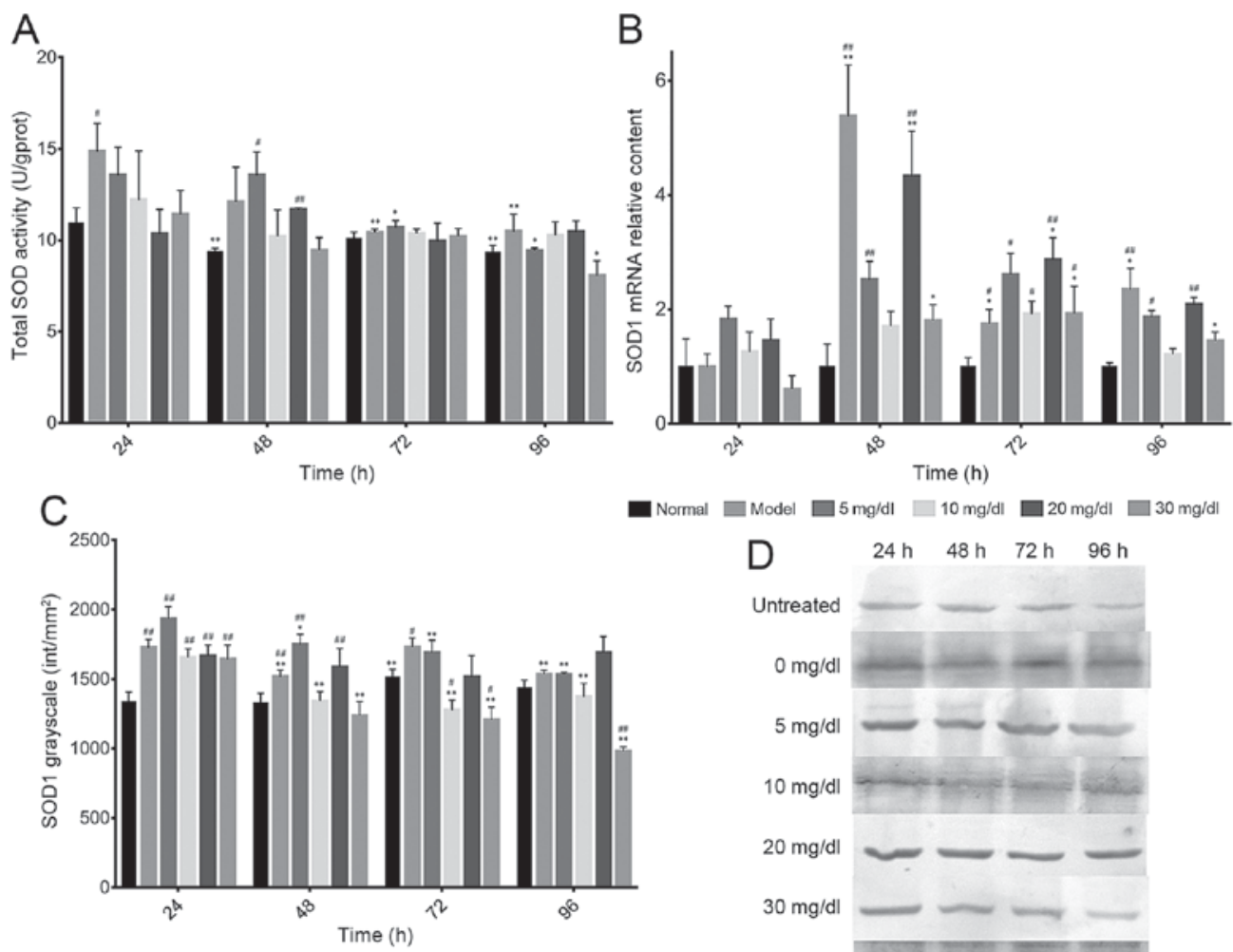

$\square$ Normal $\square$ Model $\square 5 \mathrm{mg} / \mathrm{dl} \square 10 \mathrm{mg} / \mathrm{dl} \square 20 \mathrm{mg} / \mathrm{dll} \square 30 \mathrm{mg} / \mathrm{dl}$

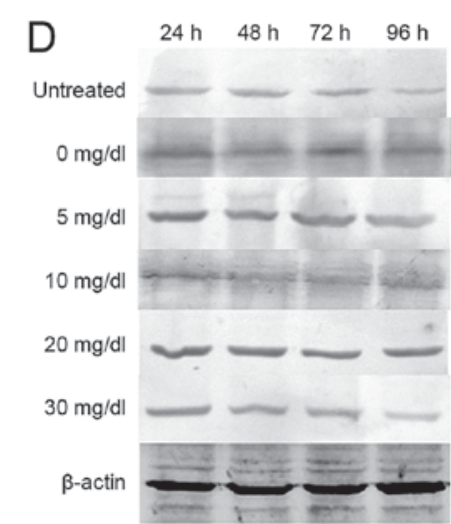

Figure 3. Activity and expression (transcriptional and translational) of SOD. The steatosis cells were treated with UA at different concentration $(0,5,10,20$ and $30 \mathrm{mg} / \mathrm{dl}$ ) and for different times (24,48, 72 and $96 \mathrm{~h}$ ); untreated cells were used as the control. (A) SOD1 activity and (B) SOD1 mRNA expression were determined. (C) SOD1 protein expression was measured via (D) western blotting. ${ }^{*} \mathrm{P}<0.05$ and ${ }^{* *} \mathrm{P}<0.01$ vs. $24 \mathrm{~h}$ cells within the same UA concentration;

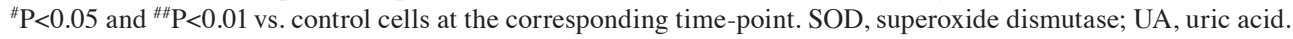



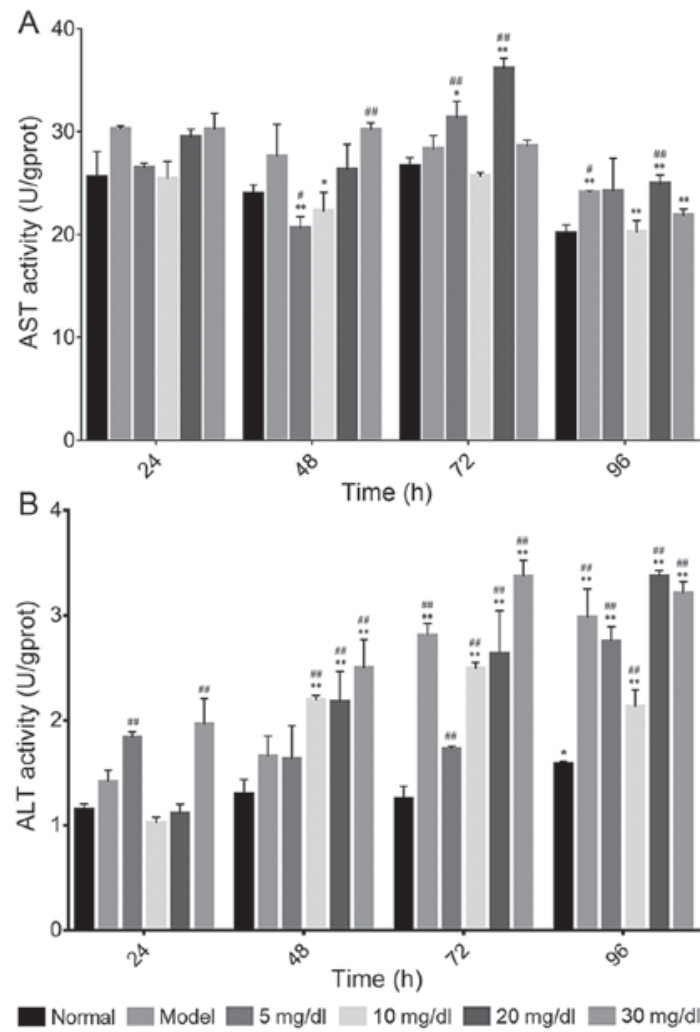

Figure 4. Activity of AST and ALT. The steatosis cells were treated with UA at different concentrations $(0,5,10,20,30 \mathrm{mg} / \mathrm{dl})$ and for different times (24, 48, 72 and $96 \mathrm{~h}$ ); untreated cells were used as the control. (A) ALT and (B) AST activity were determined. ${ }^{*} \mathrm{P}<0.05$ and ${ }^{* *} \mathrm{P}<0.01$ vs. $24 \mathrm{~h}$ cells within the same UA concentration; ${ }^{\#} \mathrm{P}<0.05$ and ${ }^{\# \#} \mathrm{P}<0.01$ vs. control cells at the corresponding time-point. ALT, alanine aminotransferase; AST, aspartate aminotransferase; UA, uric acid.

higher than that of the untreated group at $48 \mathrm{~h}$. With the exception of the $20 \mathrm{mg} / \mathrm{dl}$ group, all the other groups had reduced transcription levels in steatosis cells at $48 \mathrm{~h}(\mathrm{P}<0.05)$. The 5 and $10 \mathrm{mg} / \mathrm{dl}$ groups did not show any differences. However, the transcription level of the $5 \mathrm{mg} / \mathrm{dl}$ group was still higher than that of the untreated group at 48 and $72 \mathrm{~h}(\mathrm{P}<0.05)$. All of the UA-treated groups showed no significantly difference at $96 \mathrm{~h}(\mathrm{P}>0.05)$. The 10 and $30 \mathrm{mg} / \mathrm{dl}$ groups did not show any differences with the untreated group over the course of the experiment $(\mathrm{P}>0.05)$. The translation of SOD1 (Fig. 3C and D) in the model cells was higher than that of untreated cells until $96 \mathrm{~h}(\mathrm{P}<0.05)$. All the UA-treated groups showed higher translation levels than the untreated group at $24 \mathrm{~h}$. The $10 \mathrm{mg} / \mathrm{dl}$ group had a lower level compared to the model group from 48 to $96 \mathrm{~h}$, although not significantly different. The $30 \mathrm{mg} / \mathrm{dl}$ group had a tendency declined over time, especially at $96 \mathrm{~h}$ $(\mathrm{P}<0.05)$. However, the other groups showed no consistent trends.

Intracellular AST and ALT. From the Fig. 4A, there was not a difference in the untreated group and the model group until $96 \mathrm{~h}$ ( $\mathrm{P}>0.05)$. The $10 \mathrm{mg} / \mathrm{dl}$ group had no differences compared to the untreated group, and the $20 \mathrm{mg} / \mathrm{dl}$ group showed no differences compared with model group from 24 to $72 \mathrm{~h}$. The $5 \mathrm{mg} / \mathrm{dl}$ group and $20 \mathrm{mg} / \mathrm{dl}$ group showed lower AST levels at $48 \mathrm{~h}$ compared with their level at $24 \mathrm{~h}(\mathrm{P}<0.05)$, and then increased at $72 \mathrm{~h}(\mathrm{P}<0.05)$, declined at $96 \mathrm{~h}(\mathrm{P}<0.05)$. In ALT (Fig. 4B), except for the $10 \mathrm{mg} / \mathrm{dl}$ group, all the groups had a tendency of increasing over time. There was no difference among the first two time-points compared to the untreated group; however, at the last time-point, a slight increase was observed $(\mathrm{P}<0.05)$. Compared to the treated group, the activity of all other groups was higher. The $10 \mathrm{mg} / \mathrm{dl}$ group decreased to the level of the untreated group at $96 \mathrm{~h}(\mathrm{P}>0.05)$. The $30 \mathrm{mg} / \mathrm{dl}$ group showed the highest level among all groups from 48 to $72 \mathrm{~h}(\mathrm{P}<0.05)$. We found that the ALT in $10 \mathrm{mg} / \mathrm{dl}$ group at $96 \mathrm{~h}$ stopped increasing and it was significantly lower than the model cells.

\section{Discussion}

In the recent two years of the studies correlated to the NAFLD and uric acid, the authors paid primary attention to the relationship between developing of NAFLD and the concentration of SUA (serum uric acid). For example, Zheng et al (19) collected 95924 people from the First Affiliated Hospital of Chongqing Medical University during 2011 to 2014, they found a positive relationship between the concentration of uric acid and the developing of NAFLD, justified the age, BMI and waistline. Fu et al (20) carried out a cross-section study which 5628 people included. They discovered the increased morbidity of metabolic syndrome and NAFLD accompanied with the increased SUA. In addition, Zhou et al (21) found the higher of the SUA level the lower the probability to attenuate the progression. There was not some mechanism studies, and as an antioxidant, uric acid was rarely researched. There were two aspects about the mechanism that uric acid could induce oxidative stress under the existing information studies.

The first is that xanthine oxidase could catalyzed xanthine to uric acid accompanied with generating of ROS, with the substrate of the XO increased, the uric acid and the ROS increased either. With the duration of the stimulation of excess ROS, the OS would generate (22). The second is uric acid could access in cell to generate ROS through NOX (NADPH oxidase) (23), but this viewpoint mainly got from the studies on adipocytes, we did not clear whether this would happen in the hepatocytes.

The features of intracellular OS are the decline of antioxidants and the increase of oxidative products. Living organisms are protected against oxidative damage by enzymatic or non-enzymatic antioxidant molecules such as SOD and GSH (24). GSH is a reductant in oxidation reactions resulting in the formation of GSSG by the catalytic acitivty of GSH-px (25). The catalysis by GCL (glutamate cysteine ligase) is the rate-limiting step in GSH biosynthesis (26). Superoxide is dismutated to hydrogen peroxide, a far less reactive product, by the action of a family of metalloenzymes known as SOD (27).

In this study, the content of GSH in the model group at each time-point was significantly lower than that in the untreated group, as indicated by enzyme activity. This may be because of the oxidative stress induced by steatosis. As mentioned above, UA is a bifunctional substance. From this result, we found that the $10 \mathrm{mg} / \mathrm{dl}$ treatment has the ability to lower OS to a level similar to that of the untreated group. However, the higher concentration groups did not show enhancement in the levels of GSH in model cells. The transcription levels of $\gamma$-GCLC 
in all the groups tended to be lower compared to the model cells. However, 5 and $10 \mathrm{mg} / \mathrm{dl}$ groups showed low levels of transcription at all time-points. The translation of $\gamma$-GCLC in the $5 \mathrm{mg} / \mathrm{dl}$ group declined before $96 \mathrm{~h}$ and then was stabilized at $96 \mathrm{~h}$. The $10 \mathrm{mg} / \mathrm{dl}$ group and $20 \mathrm{mg} / \mathrm{dl}$ group did not have a stabilizing effect. The GSH-related indexes suggest that $30 \mathrm{mg} / \mathrm{dl}$ UA can aggravate the OS, and 5 and $10 \mathrm{mg} / \mathrm{dl}$ may have a protective role.

SOD is the main free-radical scavenger that can significantly reduce free radical damage to the body. It is an active substance generated by living organisms, which can eliminate harmful materials such as free radicals produced during normal oxygen metabolism (28). It can react with oxygen free radicals to generate hydrogen peroxide (29); the latter is converted into water by the organism and excreted. Thus, SOD1 activity represents the free radical scavenging ability of the body. Lipid peroxidation and bodily damage are also concomitantly increased. Under normal conditions, SOD1 release would also gradually increase to maintain the balance between oxidation and antioxidation (30). Before the experiment, we predicted that under the oxidative stress of the model group, the activity and the transcription, as well as the translation of SOD1 would be lower than that of the untreated group, and that of one or more UA-treated groups would be higher than the model group; however, in this study, we did not observe this phenomenon. The activity and translation of SOD in the model group was higher than the untreated group. This is contrary to the results of Jiang et al (31). The reason for this might be that the accumulation of fat in the model cells could not induce stress enough to reduce SOD. With the increased demand for antioxidants, the translation of SOD increased to adapt to the increased oxidizability. However, with the increase of SOD level, no matter the translation or activity, we observed that 10 and $30 \mathrm{mg} / \mathrm{dl}$ UA treatment relaxed the demands for SOD1 at 24 and $48 \mathrm{~h}$, but only $10 \mathrm{mg} / \mathrm{dl}$ stop the SOD1 from continuously increasing or decreasing. From the result of RT-qPCR, all of the treated groups had high transcription levels of SOD1 relative to that of untreated cells at $48 \mathrm{~h}$, and all the UA-treated groups had lowered transcription levels of SOD1. Interestingly, the demand for SOD1 in the model cells seemed to gradually decline, and there was no statistical difference after $72 \mathrm{~h}$ between the untreated cells and the model cells. The same phenomenon was found in the results for the transcription of $\gamma$-GCLC. We guessed that the fat accumulated in cells was metabolized gradually over time, and the model cells recovered from the oxidative stress. In other words, the oxidative stress was relaxed gradually in the model cells, and compared to SOD1, GSH might the more sensitive indicator of OS in this experiment because of the low GSH levels from the beginning to the end.

MDA is a toxic end product of lipid peroxidation, and its content can directly reflect the rate and extent of lipid peroxidation and indirectly reflect the capacity for eliminating free radicals (32). In our study, the MDA content increased depending on the time, and the 5 and $10 \mathrm{mg} / \mathrm{dl}$ treatment groups showed decreased MDA content at each of the time-points compared with model cells. This reflects a relaxed intracellular OS.

Serum aminotransferase, especially ALT, has become the standard biomarker for detection of liver injury (33). But it is rare to study the relationship between the cell damage by OS and intracellular aminotransferase. In our study, we found the ALT activity increased in a time-dependent manner. It seems that $10 \mathrm{mg} / \mathrm{dl} \mathrm{UA}$ at $96 \mathrm{~h}$ has a beneficial effect. However, for AST, we could not found a tendency dependent on time, This result conflicts with that of Wang et al (17), and it needs to be further researched. ALT is the enzyme that catalyzes the conversions of $\alpha$-ketoglutarate to glutamate and pyruvic acid to alanine and is a rate-controlling enzyme for gluconeogenesis in the liver (34). AST is the enzyme that catalyzes the conversion of oxaloacetate to aspartate (35). Oxaloacetate and $\alpha$-ketoglutarate are important intermediates in the tricarboxylic acid cycle (TCA). The $\alpha$-ketoglutarate/glutamate pair and oxaloacetate/aspartate pair have strategically important roles in amino acid metabolism. However, the correlation, as well as the mechanism, between the two transaminases and degree of cell damage intracelluler is not clear. As NAFLD is a disorder of energy metabolism, AST and ALT may play roles and are thus merit further study.

From the above, we found that the concentration under $10 \mathrm{mg} / \mathrm{dl}$ (included) could serve as an antioxidant in the steatosis hepatocytes. This is not consistent with other studies mentioned above, ROS could generate as a by-product in the uric acid generation in preceding introduction, but our intervention via UA had no correlation with UA generating in organism, so do the ROS. So, we could say these two behaviors were two different processes, it's not strange we got different result compare to the in vivo studies. The antioxidative activity could occur in the brain, being a protector for several disease such as multiple sclerosis and neurodegenerative disease, as well as cardiac and renal toxicity in another study (16). We think this beneficial may also be speculated on the liver.

We found that treatment with 5 and $10 \mathrm{mg} / \mathrm{dl}$ UA caused a relaxing effect on OS in our steatosis cell model. Additionally, $30 \mathrm{mg} / \mathrm{dl}$ UA may aggravate OS. We suggest that UA may have a protective role in OS.

The steatosis cell model created with $0.3 \mathrm{mM}$ OA treatment for $24 \mathrm{~h}$ is not sufficient to induce a decrease in intracelluar SOD1; thus, a better model should be the focus of future study.

\section{Acknowledgements}

This study was supported by First Affiliated Hospital of Xinjiang Medical University and School of Public Health of Xinjiang Medical University and we thank them for their technical assistance. Research partially supported by the Natural Science Foundation of the Xinjiang Uygur Autonomous Region, China (no. 2015211C011 to L. Ma), which appropriated 70 thousand RMB for funds to carry this research out.

\section{References}

1. Gori M, Simonelli MC, Giannitelli SM, Businaro L, Trombetta M and Rainer A: Investigating nonalcoholic fatty liver disease in a liver-on-a-chip microfluidic device. PLoS One 11: e0159729, 2016.

2. Cheung $\mathrm{O}$ and Sanyal AJ: Recent advances in nonalcoholic fatty liver disease. Curr Opin Gastroenterol 26: 202-208, 2010.

3. Gan L, Xiang W, Xie B and Yu L: Molecular mechanisms of fatty liver in obesity. Front Med 9: 275-287, 2015. 
4. Karadeniz G, Acikgoz S, Tekin IO, Tascýlar O, Gun BD and Cömert M: Oxidized low-density-lipoprotein accumulation is associated with liver fibrosis in experimental cholestasis. Clinics (Sao Paulo) 63: 531-540, 2008.

5. Gentric G, Maillet V, Paradis V, Couton D, L'Hermitte A Panasyuk G, Fromenty B, Celton-Morizur S and Desdouets C: Oxidative stress promotes pathologic polyploidization in nonalcoholic fatty liver disease. J Clin Invest 125: 981-992, 2015.

6. Fiskum G, Rosenthal RE, Vereczki V, Martin E, Hoffman GE, Chinopoulos $\mathrm{C}$ and Kowaltowski A: Protection against ischemic brain injury by inhibition of mitochondrial oxidative stress. J Bioenerg Biomembr 36: 347-352, 2004.

7. Satapati S, Kucejova B, Duarte JA, Fletcher JA, Reynolds L, Sunny NE, He T, Nair LA, Livingston KA, Fu X, et al: Mitochondrial metabolism mediates oxidative stress and inflammation in fatty liver. J Clin Invest 125: 4447-4462, 2015.

8. Browning JD and Horton JD: Molecular mediators of hepatic steatosis and liver injury. J Clin Invest 114: 147-152, 2004.

9. Xiao J, Ho CT, Liong EC, Nanji AA, Leung TM, Lau TY, Fung ML and Tipoe GL: Epigallocatechin gallate attenuates fibrosis, oxidative stress, and inflammation in non-alcoholic fatty liver disease rat model through TGF/SMAD, PI3 K/Akt/FoxO1, and NF-kappa B pathways. Eur J Nutr 53: 187-199, 2014.

10. Sanyal AJ, Campbell-Sargent C, Mirshahi F, Rizzo WB Contos MJ, Sterling RK, Luketic VA, Shiffman ML and Clore JN: Nonalcoholic steatohepatitis: Association of insulin resistance and mitochondrial abnormalities. Gastroenterology 120 : 1183-1192, 2001

11. Chalasani N, Deeg MA and Crabb DW: Systemic levels of lipid peroxidation and its metabolic and dietary correlates in patients with nonalcoholic steatohepatitis. Am J Gastroenterol 99: 1497-1502, 2004.

12. Yesilova Z, Yaman H, Oktenli C, Ozcan A, Uygun A, Cakir E, Sanisoglu SY, Erdil A, Ates Y, Aslan M, et al: Systemic markers of lipid peroxidation and antioxidants in patients with nonalcoholic Fatty liver disease. Am J Gastroenterol 100: 850-855, 2005.

13. Ames BN, Cathcart R, Schwiers E and Hochstein P: Uric acid provides an antioxidant defense in humans against oxidant- and radical-caused aging and cancer: A hypothesis. Proc Natl Acad Sci USA 78: 6858-6862, 1981.

14. Bonora E, Targher G, Zenere MB, Saggiani F, Cacciatori V, Tosi F, Travia D, Zenti MG, Branzi P, Santi L and Muggeo M: Relationship of uric acid concentration to cardiovascular risk factors in young men. Role of obesity and central fat distribution. The verona young men atherosclerosis risk factors study. Int J Obes Relat Metab Disord 20: 975-980, 1996.

15. Yoo TW, Sung KC, Shin HS, Kim BJ, Kim BS, Kang JH, Lee MH, Park JR, Kim H, Rhee EJ, et al: Relationship between serum uric acid concentration and insulin resistance and metabolic syndrome. Circ J 69: 928-933, 2005.

16. Lombardi R, Pisano G and Fargion S: Role of serum uric acid and ferritin in the development and progression of NAFLD. Int J Mol Sci 17: 548, 2016.

17. Wang JW, Wan XY, Zhu HT, Lu C, Yu WL, Yu CH, Shen Z and Li YM: Lipotoxic effect of p21 on free fatty acid-induced steatosis in L02 cells. PLoS One 9: e96124, 2014.

18. Lanaspa MA, Sanchez-Lozada LG, Choi YJ, Cicerchi C, Kanbay M, Roncal-Jimenez CA, Ishimoto T, Li N, Marek G, Duranay M, et al: Uric acid induces hepatic steatosis by generation of mitochondrial oxidative stress: Potential role in fructose-dependent and -independent fatty liver. J Biol Chem 287: 40732-40744, 2012.

19. Zheng X, Gong L, Luo R, Chen H, Peng B, Ren W and Wang Y: Serum uric acid and non-alcoholic fatty liver disease in non-obesity Chinese adults. Lipids Health Dis 16: 202, 2017.

20. Fu YQ, Yang H, Zheng JS, Zeng XY, Zeng W, Fan ZF, Chen M, Wang $\mathrm{L}$ and $\mathrm{Li}$ D: Positive association between metabolic syndrome and serum uric acid in Wuhan. Asia Pac J Clin Nutr 26: 343-350, 2017
21. Zhou Z, Song K, Qiu J, Wang Y, Liu C, Zhou H, Xu Y, Guo Z, Zhang $B$ and Dong C: Associations between serum Uric acid and the remission of non-alcoholic fatty liver disease in chinese males. PLoS One 11: e0166072, 2016.

22. Kushiyama A, Nakatsu Y, Matsunaga Y, Yamamotoya T, Mori K, Ueda K, Inoue Y, Sakoda H, Fujishiro M, Ono H and Asano T: Role of Uric acid metabolism-related inflammation in the pathogenesis of metabolic syndrome components such as atherosclerosis and nonalcoholic steatohepatitis. Mediators Inflamm 2016: 8603164, 2016.

23. Sautin YY, Nakagawa T, Zharikov S and Johnson RJ: Adverse effects of the classic antioxidant uric acid in adipocytes: NADPH oxidase-mediated oxidative/nitrosative stress. Am J Physiol Cell Physiol 293: C584-C596, 2007.

24. Valavanidis A, Vlachogianni T, Fiotakis K and Loridas S: Pulmonary oxidative stress, inflammation and cancer: Respirable particulate matter, fibrous dusts and ozone as major causes of lung carcinogenesis through reactive oxygen species mechanisms. Int J Environ Res Public Health 10: 3886-3907, 2013.

25. Annuk M,Zilmer M, Lind L, Linde T and Fellström B: Oxidative stress and endothelial function in chronic renal failure. J Am Soc Nephrol 12: 2747-2752, 2001.

26. Chen Y, Shertzer HG, Schneider SN, Nebert DW and Dalton TP: Glutamate cysteine ligase catalysis: Dependence on ATP and modifier subunit for regulation of tissue glutathione levels. J Biol Chem 280: 33766-33772, 2005

27. Vaziri ND, Dicus M, Ho ND, Boroujerdi-Rad L and Sindhu RK: Oxidative stress and dysregulation of superoxide dismutase and NADPH oxidase in renal insufficiency. Kidney Int 63: 179-185, 2003.

28. Broxton $\mathrm{CN}$ and Culotta VC: SOD enzymes and microbial pathogens: Surviving the oxidative storm of infection. PLoS Pathog 12: e1005295, 2016.

29. Kondo Y, Masutomi H, Noda Y, Ozawa Y, Takahashi K, Handa S, Maruyama N, Shimizu T and Ishigami A: Senescence marker protein-30/superoxide dismutase 1 double knockout mice exhibit increased oxidative stress and hepatic steatosis. FEBS Open Bio 522-532, 2014

30. Li XD, Sun GF, Zhu WB and Wang YH: Effects of high intensity exhaustive exercise on SOD, MDA, and NO levels in rats with knee osteoarthritis. Genet Mol Res 14: 12367-12376, 2015.

31. Jiang J, Yu S, Jiang Z, Liang C, Yu W, Li J, Du X, Wang H, Gao X and Wang X: N-acetyl-serotonin protects HepG2 cells from oxidative stress injury induced by hydrogen peroxide. Oxid Med Cell Longev 2014: 310504, 2014.

32. Zhou F, Sun W and Zhao M: Controlled formation of emulsion gels stabilized by salted myofibrillar protein under malondialdehyde (MDA)-induced oxidative stress. J Agric Food Chem 63: 3766-3777, 2015

33. Thulin P, Rafter I, Stockling K, Tomkiewicz C, Norjavaara E, Aggerbeck M, Hellmold H, Ehrenborg E, Andersson U, Cotgreave I and Glinghammar B: PPARalpha regulates the hepatotoxic biomarker alanine aminotransferase (ALT1) gene expression in human hepatocytes. Toxicol Appl Pharmacol 231: $1-9,2008$

34. Liu L, Zhong S, Yang R, Hu H, Yu D, Zhu D, Hua Z, Shuldiner AR, Goldstein R, Reagan WJ and Gong DW: Expression, purification, and initial characterization of human alanine aminotransferase (ALT) isoenzyme 1 and 2 in High-five insect cells. Protein Expr Purif 60: 225-231, 2008 .

35. Xu Q, Higgins T and Cembrowski GS: Limiting the testing of AST: A diagnostically nonspecific enzyme. Am J Clin Pathol 144: 423-426, 2015. 